\title{
MORTON M. MCCARVER: AN IOWA ENTREPRENEUR IN THE FAR WEST
}

\author{
by Michael B. Husband \\ Albuquerque, New Mexico
}

Mr. Husband is currently a doctoral candidate in the department of history at the University of New Mexico. He also teaches American and Western American history for the University of Albuquerque.

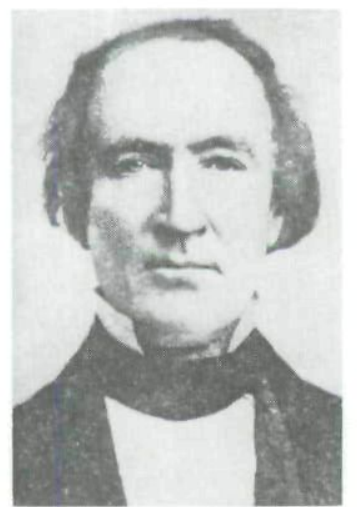

Morton McCarver

Morton Matthew McCarver was born under a wandering star. The westward movement is well exemplified in his life and in his far-reaching enterprises, and his career as city planner and founder, speculator, merchant, farmer and public servant is inseparably linked with the history of different sections of the country. Born near the wilderness town of Lexington, Kentucky, on Jan. 14, 1807, McCarver's restless temper manifested itself at an early age. Betsey Morton McCarver was a leader in the Shaker sect, and the rather narrow, stern atmosphere engendered by her deep spiritual convictions at once repelled her inquisitive son and instilled in him some of the characteristics that were to distinguish him in later life. When McCarver left home at 14, his mother considered him to be "dead," and she thereafter refused to see him again.

The years following the War of 1812 brought about a remarkable era of change in the vast lands to the north, the south and the west; Florida was acquired from Spain, General Jackson had seemingly effected a solution to the Indian problem, and Indiana, Mississippi, Illinois and Missouri became states in the Union. Occasional newspapers brought news of steamboats and of the romance of New Orleans and 
Texas to backwoods readers. Like so many other active sons of the wilderness, young McCarver, in 1821, received his introduction to the outside world by a flatboat trip down the Ohio and Mississippi Rivers.

The next few years saw McCarver wandering throughout Louisiana and Texas. He discovered, however, that the Southern states were not to his liking-a poor young man had little chance for advancement there. He remained for a brief period in Texas, then under the flag of Mexico, but found that the discordant society and the Indian depredations rendered that land all but useless to one desirous of establishing a home and living in accordance with the rules of a civilized society. Thoroughly convinced that there was nothing for him in the country to the south, McCarver ascended the Mississippi, this time by steamboat, and returned to Lexington.

Rejected by his mother, McCarver was nevertheless welcomed by his old friends, and the young traveler obtained employment and continued his self-education, hoping one day to become a doctor of medicine. Despite his love for Kentucky, McCarver, repelled by certain conditions in that state (he harbored a strong belief that social tranquility would require an effective separation of the white and black races) and prompted by a burning desire to seek his fortune, moved to Illinois in 1829. True to his nature, he did not settle in one place, but rather spent time at Galena and Monmouth, at Rock Island and elsewhere. He remained in Illinois for four years, and acquired property and money, a wife and two children and a determination to make his future home on the western side of the Mississippi.

The object of McCarver's attention was the land, now eastern Iowa, that belonged to the Sac and Fox Indians. When the Black Hawk War broke out, McCarver joined the Illinois troops, and was present when Black Hawk's vanquished tribe signed the treaty of Sept. 21, 1832 by which they gave up the lands that later became eastern Iowa. The treaty stipulated that the land should not be opened to settlement until June 1, 1833, but McCarver, impatient by nature, conceived the idea of founding a city in that region that would become 
one of the great commercial centers of the West. The site that he selected for a town was a rocky bluff which the fur traders called Flint Hills. McCarver's interest in the area was shared by two kinsmen, Amzi Doolittle and Simpson S. White, and within two weeks of the signing of the treaty, this triumvirate of brothers-in-law crossed the Mississippi, laid claim to the Flint Hills, and erected their cabins. Although one of the anxious pioneers wrote that "We did not feel that we were infringing on the rights of the Indians by making our claims," ${ }^{1}$ a small company of soldiers arrived from Fort Armstrong to drive them away. ${ }^{2}$ When the legal date for settlement arrived, the determined men returned to begin the business of building a town.

Dr. William R. Ross, a surveyor, arrived at Flint Hills in July, 1833, and was employed by McCarver, Doolittle and White to divide a portion of their land into lots, blocks and streets. In early 1834, John B. Gray of Burlington, Vermont, arrived and insisted that the new settlement be named "Burlington" in honor of his former home. ${ }^{3}$ Gray opened Burlington's first grocery business, Ross established a trading enterprise, and McCarver engaged in the Indian trade, speculation in land and in the lead mines at Dubuque and in the cultivation of his fields. In addition, he and his two partners operated a flat-bottomed ferry boat used to transport settlers across the Mississippi to the new town.

During 1834, Burlington was further surveyed and a number of town lots were sold. In September, McCarver, in the presence of citizens and soldiers at the present site of Montrose, read a proclamation by Governor Stevens T. Mason of Michigan Territory declaring that the laws of Michigan and of the United States had been extended over the "Black Hawk Purchase." Immigrants to Burlington in 1836 found a flourishing settlement with a population of "perhaps 200 or 300 ,"

\footnotetext{
${ }^{1}$ History of Des Moines County, Iowa, 469. Chicago: Westem Historical Company, 1879.

${ }^{2}$ Fort Armstrong was located on the lower end of Rock Island in the Mississippi River, between Rock Island, Illinois and Davenport, Iowa. ${ }^{3}$ Letter of John B. Gray, Burlington Hawkeye, Burlington, Iowa: April 6, 1861.
} 
according to one William Garrett, who arrived in April of that year. ${ }^{4}$ John B. Newhall, the most influential promoter of Iowa prior to 1850 , noted the Iowa-bound human tide:

\begin{abstract}
... the roads would be literally lined with the long blue wagons of the emigrant slowly wending their way over the broad prairies - the cattle and hogs, men and dogs, and frequently women and children, forming the rear of the van often ten, twenty, and thirty wagons in company. Ask them, when and where you would, their destination was the Black Hawk Purchase. ${ }^{5}$
\end{abstract}

In 1836, when Iowa was transferred to the jurisdiction of Wisconsin Territory, Congress enacted a law donating 640 acres for town purposes to each of the towns of Peru, Dubuque, Bellevue, Madison, Mineral Point and Burlington. McCarver was appointed one of three commissioners to carry out the provisions of this law. Iowa became a territory in 1838, and Burlington, much to the satisfaction of its founders, was designated as the first territorial capital. In January, 1839, Governor Robert Lucas, as commander in chief of the Iowa military forces, appointed McCarver commissary general. The title of "General" stayed with him throughout his lifetime.

General McCarver did not confine himself to the expansion of Burlington while in Iowa. In addition to his various commercial activities, he traveled about the Territory, and, when he tired of standing behind a counter in his mercantile store, his restless nature often rebelled sufficiently to send him to Washington, Saint Louis or Chicago to investigate the commercial possibilities in and near those cities. (He did, in fact, invest in land in Chicago, although the extent of his holdings there is unknown.)

In 1840, McCarver and his partner, Edmund Archibald surveyed and platted the settlement of McCarverstown, located west of Burlington in Henry County, Iowa. The place was first settled by Hiram C. Smith, who came with his family from Kentucky in 1833. Smith built a mill on each side

${ }^{4}$ Portrait and Biographical Album of Des Moines County, Iowa, 727. Chicago: Acme Publishing Company, 1888.

${ }^{5}$ Newhall, John B., A Glimpse of Iowa in 1846, 12-13. Reprint; Iowa City, Iowa: State Historical Society of Iowa, 1957. 
of the Chicaqua (now the Skunk River), and the settlement became known as Smith's Mills. In 1843 the name was changed to Lowell. If McCarver had grandiose plans for McCarverstown, they were foiled by the advent of the "Oregon Fever."

Of the various factors which prompted Morton McCarver to seek a new home in Oregon, the most forceful was his inherent restlessness. Other motives, however, bear some consideration. The financial depression created by the panic of 1837 had seriously affected western interests, and McCarver found himself with debts amounting to some $\$ 10,000$, all of which he later paid with money acquired on the Pacific coast. By early 1843, when the full impact of the panic had reached Iowa, it was reported that

Corn and oats could be bought at from six to ten cents per bushel, pork at a dollar a hundred, and the best kind of horses the farmers could raise would bring from fifty to sixty dollars. $^{6}$

As a result, one observer wrote that ". . . everyone was in debt, and the sheriff and constable, with a legal process, trying to collect a debt, were frequent visitors at almost every man's door."

Whatever the extent of financial suffering may have been, there were many who felt that Iowa, not Oregon, was the land of promise. The country ceded to the United States in 1842 by the Sac and Fox Indians, commonly known as the New Purchase, was to be opened for settlement on May 1, 1843. McCarver, however, was evidently unimpressed with one editor's boast that "Oregon is a small potato compared with the new Iowa purchase so far as the interests of a western settler may be concerned."

McCarver was convinced that Burlington was destined to become a good town-indeed, the best town in Iowa, but it

${ }^{6}$ Robeson, George F., "Hard Times in Early Iowa," The Palimpsest, Vol. V, 165. Iowa City, Iowa: State Historical Society, May, 1924.

${ }^{7}$ Ibid., 165-66.

${ }^{8}$ Grahame, Pauline, "The Promised Land," The Palimpssst, Vol. X, 187, May, 1929. 
would never compare with New Orleans, Cincinnati or Saint Louis. The settlers of Iowa were spreading out into agricultural communities, but Oregon would spawn great new urban commercial centers. Explorers and missionaries publicized the rich Willamette Valley, and the "Oregon Fever" began to take its toll in the early 1840 s. By 1842, emigrating societies existed in all parts of the country, and Oregon meetings were held in numerous cities and towns, including Bloomington (now Muscatine), and Iowa City. Enterprising Dubuque citizens even advocated a railroad to Oregon to facilitate emigration. A letter from Iowa Territory, written in 1843, described the "Oregon Fever" there:

I suppose you of the east consider the present residents of Iowa the very pioneers of the west. Never was a greater mistake; the true western pioneers have pushed on beyond us, or if here and there one still lingers, it is only that he may dispose of his farm and 'improvements' and move on to a 'new country.' .... And on-on-on he goes, always seeking and never attaining the Pisgah of his hopes. ... Just now Oregon is the pioneer's land of promise. . . the Oregon fever has broken out, and is now raging like any other contagion. . . .9

Sensing the temptations held out to pioneers by the Oregon propaganda, Senator Lewis F. Linn of Missouri urged the Senate to organize the Oregon territory and to stimulate emigration thereto by offering 610 acres of land to every settler. Linn's bill was not destined to become law, but to the would-be Oregonians, a hint was as good as a promise.

Thus a combination of circumstances presented an irresistable lure to Morton McCarver's restless temper, and it was with great difficulty that he resisted the temptation to join the Oregon migration of 1842. During the last months of that year, McCarver made his arrangements and perfected his plans, and in May, 1843, leaving his family in Iowa, he joined the "Great Migration" of nearly 1,000 persons then assembling a few miles west of Independence, Missouri. The 1843 migration was the first large home-building expedition to the Northwest, and the movement was instrumental in demonstrating the American claim to the Oregon Country. During the organization of the company, McCarver was made

'Niles' National Register. Baltimore, Maryland: April 22, 1843. 
one of the Council of nine men who were to have general charge of the expedition.

There are several colorful journals and numerous letters which capture the flavor of the 1843 overland trek. The letters of Morton McCarver reflected his characteristic optimism and served to advise future Oregon pioneers of the joys and sorrows of such a journey. A perusal of his letters, as well as those of several of his traveling companions, indicates that the trip was far less arduous than one might expect. In a letter dated June 10, 1843, written from a point "between 2 and 300 miles west of Independence," McCarver had encouraging news for those at home who might be contemplating the trip in the future:

... Our roads, since leaving the settlements have been very fine, except within the last few days, during which period they have been almost impassable in consequence of the tremendous rains, but they are again improving. We have had no trouble with the Indians, with the exception of horse and cattle stealing, and this business they have carried on pretty lively. . . . I believe there is not a case of sickness in the camp, though old Mr. Stout, from Iowa, has a violent swelling in his eyes. Tell the boys from Iowa to come on with all the cattle and sheep they can get, and a company large enough to drive them. ${ }^{10}$

And on July 13, from Fort Laramie, McCarver wrote as follows:

... I do not believe a road equally good and of the same length can be found in the States ... Say to those who think of emigrating that the trip to Oregon is not such a bug-a-boo as it is represented to be. All that it requires is patience and perserverence. ${ }^{11}$

Once on the Pacific coast, no more ardent Oregon "booster" than Morton McCarver could be found. In a letter to A. C. Dodge, an old friend and a delegate to Congress from Iowa, written shortly after the arrival of the migration, McCarver stated:

${ }^{10}$ Missouri Republican. Saint Louis, Missouri: August 7, 1843. McCarver's numerous errors in spelling and punctuation have been corrected in all letters cited for clarity.

${ }^{11}$ Ohio State Journal. Columbus, Ohio: December 4, 184.3. 
Perhaps there is no country in the world of its size that offers more inducements to enterprise and industry than Oregon. The soil in this valley [the Willamette] and in many other portions of the territory is equal to that of Iowa, or any other portion of the United States, in point of beauty and fertility, and its productions in many articles are far superior . . . there is now growing in the field of Mr. James Johns, less than a mile from this place ... a turnip measuring in circumference four and one half feet, and he thinks it will exceed five feet before pulling time. . . . ${ }^{12}$

True to his town-building instinct, McCarver formed an agreement with Peter $\mathrm{H}$. Burnett to build a town on the Willamette River in the Oregon Country. The place, founded in the winter of 1843-44, was called Linnton, in honor of Senator Lewis F. Linn of Missouri. The partners assumed that Linnton would become a great commercial center, but many years later, Burnett admitted that Linnton "was a fair site, except for one small reason: it was not at the head of ship navigation. . .." ${ }^{\prime 3}$ Oregon City, at the falls of the Willamette, was nearer to the farming lands, but Portland arose a few miles upriver and overshadowed both Oregon City and Linnton. McCarver later claimed that the real reason for the failure at Linnton was a lack of nails for the construction of buildings.

Sensing that the Linnton enterprise was unprofitable, McCarver pursued a career as a farmer on his claim on the Tualatin Plains. In late 1843, he sent for his family, hoping that they would come to the Oregon Country with an overland migration in 1844. His letter, however, took ten months to reach Iowa, and his family did not arrive until 1845. (McCarver's first wife died in 1846. Two years later, he married a widow, Julia A. Buckalew. Two children came with their mother in 1845, and five more were born to McCarver and his second wife.)

Meanwhile, the General had selected new properties in and near Oregon City. In addition, he assumed a prominent role in Oregon politics. In June, 1844, the Oregon legislative

${ }^{12} \mathrm{McC}$ Carver to A. C. Dodge, November 6, 1843, Oregon Historical Quarterly, Vol. IV, 78-79, March, 1903; reprinted from the Ohio Statesman of September 11, 1843.

${ }^{13}$ Burnett, Peter H., "Recollections and Opinions of an Old Pioneer," Oregon Historical Quarterly, Vol. V, 90, March, 1904. 
committee, assembling in Oregon City, elected McCarver to the office of speaker. In this capacity he must have felt much at home, for in July, 1843, the first legislative committee of the Provisional Government had adopted as the law of the land nearly the entire body of laws enacted by the legislature of Iowa Territory at Burlington during its first session in 1838-39. The McCarver committee enacted a number measures, including a stringent prohibition law and a statute banning slavery and directing Negroes who might find their way to Oregon to leave the territory within a specified period of time.

Such questions, however, as slavery, prohibition and the increasingly tense Oregon boundary dispute could not keep McCarver in Oregon when, in August, 1848, news of the discovery of gold in California reached Oregon City. The discovery of gold, the commercial promise and the change in government as a result of the war with Mexico created considerable excitement in Oregon, and for some time, life in Oregon seemed dull in contrast with the activity in California. Many Oregonians joined the rush to the gold fields, and General McCarver was among the first to go.

McCarver secured a claim on the Feather River and did rather well at mining, but the "townsite fever" soon gripped him again, and he entered into an agreement with John Sutter and his son to build a town on their land. McCarver suggested the sale of lots, and offered to manage the enterprise. The offer was accepted, and an engineer was hired to survey and plat the town, which they called Sacramento. In December, 1848, McCarver's old partner, Peter Burnett, who had been mining and was now seeking a change of occupation, became acquainted with the younger Sutter and secured for himself the business of managing the scheme that had been promised to McCarver. Burnett is said to have made $\$ 100,000$ in handling the property, and McCarver never forgave him.

Although chagrined at this turn of events, McCarver nevertheless purchased a number of lots in the new town, became a landlord and a merchant, and operated a schooner in trade with the San Francisco Bay area. In a letter to a friend in 
Peoria, Illinois, the General told of his success in California:

\begin{abstract}
.... We have Gold here in great abundance ... I am already satisfied with the Gold hunting, having already procured more than I had a right to expect I should get. I came to California about twelve months since and commenced mining and after making a few thousand I commenced merchandising at Sacramento City and shall continue that business until next spring when I shall retire to my farm in Oregon ... Money is almost as plenty there [Oregon] as in California, the Oregon men being the most successful miners and their produce and lumber is fetching the most exorbitant prices. . . . ${ }^{14}$
\end{abstract}

Early in 1849, the people of Sacramento seemed to require some form of civil government. Accordingly, eleven men, including McCarver, were elected members of a legislature which was impowered to enact laws for the Sacramento district. When General Riley, the military governor of California called for a convention to prepare either a plan of territorial government or a state constitution, a meeting was held in Sacramento, over which McCarver presided. General Riley's call was approved, and McCarver was elected one of the delegates to the constitutional convention which was to meet at Monterrey on Sept. 1, 1849. McCarver was one of those who worked effectively toward framing a free state document (". . . Slavery is prohibited by a unaimous vote . . .). ${ }^{15}$ In late 1849 , Peter H. Burnett, McCarver's onetime associate and friend became California's first civil governor.

McCarver had prospered in Sacramento, but having sustained heavy losses in the great flood of the winter of 184950 , he became discouraged and sold his interests there. He purchased an interest in a schooner plying between Hawaiian and Pacific coast points, and the business proved to be very profitable. Despite his success, the floods and the frequent fires, the violent market fluctuations and the pull of family and other ties brought McCarver back to Oregon in mid1850. He returned by ship and brought with him, from San Francisco, an upright piano, some furniture and a pre-cut

${ }^{14}$ McCarver to Francis Voris, September 19, 1849, California Historical Society Library, San Francisco, California.

${ }^{15} \mathrm{McC}$ Carver to Voris, September 19, 1849. 
house, cut to pattern in Boston of Maine lumber and ready to erect on his "Locust Farm" near Oregon City.

Upon his return to Oregon, General McCarver became a model agriculturist, originating three new varieties of apples and establishing an extensive fruit and nursery business. In 1853 he won a medal for the best display of fruits in the Agricultural and Horticultural Fair in San Francisco. But despite such triumphs, McCarver was unable to restrain his disposition for indulgence in enterprises other than farming. In 1852, therefore, he invested a considerable sum in a steamboat designed for use on the upper Willamette River. The boat was not a great success, and following an accident, McCarver divested himself of his share of the scheme, and for the time being contented himself with agricultural pursuits.

General McCarver's military career, initiated in Illinois and Iowa, continued in Oregon. He served in three Indian wars in Oregon, most of the time in his familiar role as commissary general. When the Indian war of $1855-56$ ended, McCarver journeyed to Washington to secure payment of the claims of those who had fought the Indians, the majority of whom had furnished all their equipment. He was unsuccessful in his efforts, however, and not until 1891 did Congress take up the matter and at last make provision for payment. While in Washington, McCarver endeavored to secure for himself the office of governor of the Oregon Territory, having learned that the current governor would not seek re-election. Again, McCarver's efforts were in vain, and he returned to Oregon with new and exciting plans for the future.

Feeling the need for a change, McCarver determined to leave Oregon City. Despite the protests of Mrs. McCarver, who was warmly attached to "Locust Farm", the General transferred his residence and business to the burgeoning city of Portland in 1858. It was not long until McCarver again fell victim to the "gold fever." When the Fraser River gold excitement broke out in 1857, he had hastened to the scene, but contented himself with purchasing a few lots in Victoria, British Columbia, which he subsequently sold at a profit. In 1862, McCarver joined another stampede to the newly discovered gold fields of Idaho. He organized the firm of McCarver, Clark and Townsend and did a thriving mercantile 
business at Bannock City (Idaho City). Crime was rampant in Idaho, and McCarver was called on to preside over one of several popular tribunals organized to mete out hasty justice to horse thieves, claim-jumpers, robbers and murderers.

Although he was doing well in Idaho, McCarver, in yet another manifestation of his restless nature, decided to undertake a new enterprise. Leaving his business to the care of his partners, in 1864 he went to New York to sell stock in western quartz mines. Unfortunately, The Civil War had disrupted business, and speculators were at that time unwilling to invest in such uncertain ventures. While he was in New York, Idaho City burned and the firm of McCarver, Clark and Townsend ceased to exist. McCarver returned to Portland and began to give serious thought to an idea that had been in his mind since his trip to the Fraser River mines. Another city was soon to be born.

McCarver became imbued with the idea that he could build a town on Puget Sound that would serve as the western terminus for the promised Northern Pacific Railroad. His pleadings finally influenced Lewis Starr and James Steel, prominent Portland bankers, to support the scheme, provided McCarver would personally direct and manage the venture. In March, 1868, at 62 years of age, McCarver mounted his horse and started alone for Puget Sound. He had studied all available maps and decided that Commencement Bay, the harbor of present day Tacoma, would become the great commercial center of the Northwest. Here, Morton McCarver founded his last city.

The new town had its beginnings on land purchased by McCarver from an early settler, and was first known as Commencement City, later as Tacoma. There is some disagreement about the changing of the name to Tacoma, but McCarver was evidentally satisfied that the name was suitable. It is likely that one of the General's acquaintances, who was also an admirer of Theodore Winthrop's book The Canoe and the Saddle, suggested the name "Tacoma." (Winthrop, scion of a famous New England family, wandered through the Puget Sound country in the 1850s gathering material for his book, in which he stated that the Indians referred to Mount Rainier 
as “Tacoma.") ${ }^{16}$

McCarver's letters from Commencement City reveal his wonderful energy and hope: "The main object of this communication is to urge the immediate construction of a first class sawmill at this place. It would at once start a town of no small pretensions. . . ." ${ }^{17}$ Several days later, he wrote: “. . . Could they (the railroad men) see the place they . . . would see at once that no place in the world is better calculated for the erection of a large city. . . ." 18

In late 1868, the sawmill was constructed, and slow but steady progress was made in the building of the town. McCarver, the moving spirit of the town, served as election officer, road supervisor, and in 1870, was made Superintendent of Schools for Pierce County, Washington Territory. In addition, he was one of the first to discover coal in the region.

As the winter of 1868 drew near, it seemed that Morton McCarver had finally found a permanent home:

... My family want to spend the winter in Portland where the children can be kept at school. Next spring or summer I shall move here permanently, everything turning out as I hope it will ... if everything works harmoniously I shall have my Bones planted when I die upon the pleasant and classical shores of Commencement Bay. ${ }^{19}$

While speculation was rife as to what point the railroad would designate as its western terminus, McCarver was confident that Tacoma would be chosen. He realized his hope in 1873; after a prolonged investigation, the following telegram arrived on July 14, 1873:

"To General McCarver:

We have located terminus on Commencement Bay.

R. D. Rice

J. C. Ainsworth

Commissioners."

${ }^{16}$ Others claimed the honor of naming Tacoma, including McCarver's son-in-law, Clinton P. Ferry; Ferry to B. S. McLafferty, February 12, 1900, McLafferty Papers, Tacoma Public Library, Tacoma, Washington.

${ }^{17}$ McCarver to Lewis Starr and James Steel, August 20, 1858, Thomas Wickham Prosch Papers, University of Washington, Seattle, Washington.

${ }^{18}$ McCarver to Starr and Steel, August 29, 1868, Prosch Papers.

${ }^{19}$ McCarver to Starr and Steel, September 17, 1868, Prosch Papers. 
It was a great disappointment to McCarver, however, when the terminus was established on the south side of the Bay at "New Tacoma", some distance from his holdings in the original settlement. Thus the General failed to reap the benefits he had anticipated from the coming of the railroad. Nevertheless, he contented himself with the realization that he had achieved the founding of a great city.

In March, 1875, McCarver saddled his horse for a trip to the coal area near Tacoma. On April 17, an illness aggravated by a cold contracted on the ride ended the life of this remarkably enterprising and energetic man. McCarver left many friends behind, one of whom was J. W. Nesmith, a prominent Oregonian and a fellow pioneer of 1843. Nesmith felt that McCarver's public services assured him of honor and respect, ". . . particularly in a country where success is the standard by which merit is determined." ${ }^{20}$

Although he was only one of many players in the great drama of the westward movement, Morton McCarver enacted a leading role as a pioneer city builder and a frontier entrepreneur.

\section{Additional Sources}

"Emigration From Iowa to Oregon in 1843," Iowa Journal of History and Politics, Vol. X (July 1912).

Goodall, Mary, Oregon's Iron Dream, Portland: Binsfords and Mort, 1958 .

Hunt, Herbert, Tacoma, Its History and Its Builders, Vol. II. Chicago: S. J. Clarke Publishing Company, 1916.

Meany, Edmond S., "Morton Matthew McCarver, Frontier City Builder," Annual Report. Washington: American Historical Association, 1911.

Oregon Historical Quarterly, Oregon Historical Society, Portland: Dale, Harrison C., "The Organization of the Oregon Emigrating Companies," (September 1915); Herriott, F. L., "Transplanting Iowa's Law to Oregon," (June 1904).

Palimpsest, Iowa State Historical Society, Iowa City: Garretson, O. A., "Lowell," (December 1928); Hall, Reeves, "Oregon Fever," (March 1943); Swisher, J. A., "Government Comes to Iowa," (February 1934); Parish, J. C., "The Beginnings of Burlington," (November 1921); Pelzer, Louis, “A Port For Pioneers," (July 1934); Petersen, William J., "To The Land of the Black Hawk," (February 1933).

Prosch, Thomas W., McCarver and Tacoma. Seattle: Lowman and Hanford, 1906.

${ }^{20} \mathrm{~J}$. W. Nesmith to Jesse Applegate, March 1, 1859, Nesmith Collection, Oregon Historical Society Library, Portland, Oregon. 
Copyright of Annals of Iowa is the property of State of Iowa, by \& through the State Historical Society of Iowa and its content may not be copied or emailed to multiple sites or posted to a listserv without the copyright holder's express written permission. However, users may print, download, or email articles for individual use. 